\title{
MATHEMATICAL MODELS TO DESCRIBE THE VOLUMETRIC SHRINKAGE RATE OF RED BEANS DURING DRYING
}

\section{PAULO C. CORRÊA ${ }^{1}$, OSVALDO RESENDE ${ }^{2}$, SILVIA A. GARIN ${ }^{3}$, CARMEN JAREN ${ }^{3}$, GABRIEL H. H. DE OLIVEIRA ${ }^{4}$}

\begin{abstract}
The present study aimed to determine the volumetric shrinkage rate of bean (Phaseolus vulgaris L.) seeds during air-drying under different conditions of air, temperature and relative humidity, and to adjust several mathematical models to the empiric values observed, and select the one that best represents the phenomenon. Six mathematical models were adjusted to the experimental values to represent the phenomenon. It was determined the degree of adjustment of each model from the value of the coefficient of determination, the behavior of the distribution of the residuals, and the magnitude of the average relative and estimated errors. The rate of volumetric shrinkage that occurred in bean seeds during drying is between 25 and $37 \%$. It basically depends on the final moisture content, regardless of the air conditions during drying. The Modified Bala \& Woods' model best represented the process.
\end{abstract}

KEYWORDS: Phaseolus vulgaris L., moisture content, volume, air-drying, physical property.

\section{MODELOS MATEMÁTICOS PARA DESCREVER A TAXA DE CONTRAÇÃO VOLUMÉTRICA DE FEIJÃO-VERMELHO DURANTE A SECAGEM}

RESUMO: O objetivo deste trabalho foi determinar a taxa de contração volumétrica de sementes de feijão (Phaseolus vulgaris L.) durante a secagem sob diferentes condições de ar, temperatura e umidade relativa, e ajustar vários modelos matemáticos para os valores empíricos observados, selecionando o que melhor representa este fenômeno. Foram ajustados seis modelos matemáticos aos dados experimentais para representar o fenômeno. Determinou-se o grau de ajuste de cada modelo através dos valores de coeficiente de determinação, do comportamento da distribuição dos resíduos e da magnitude dos erros médios relativos e estimados. A taxa de contração volumétrica que as sementes de feijão sofreram durante a secagem é em torno de 25 a $37 \%$, e é basicamente em função do teor de água final e praticamente independente das condições do ar de secagem. $\mathrm{O}$ modelo de Bala e Woods modificado foi o que melhor representou o processo.

PALAVRAS CHAVE: Phaseolus vulgaris L., teor de água, volume, secagem, propriedades físicas.

\section{INTRODUCTION}

Drying of agricultural products is the process most frequently used to ensure quality and stability during storage, inhibiting the growth of microorganisms and reducing the rates of enzymatic or non-enzymatic reactions.

Reducing grain moisture content is a complex phenomenon, which mechanisms have not been fully elucidated (RAMOS et al., 2005). It simultaneously relates heat and mass transfer processes (BROOKER et al., 1992). Mathematical models are essential to predict and simulate the behavior of the materials that undergo a certain process. Therefore, the use of mathematical models during

\footnotetext{
${ }^{1}$ Eng ${ }^{0}$ Agrônomo, Departamento de Engenharia Agrícola, Universidade Federal de Viçosa, Viçosa - MG, copace@ufv.br.

${ }^{2}$ Eng ${ }^{\mathrm{o}}$ Agrícola, Prof. Dr., IF Goiano, Câmpus Rio Verde, Rodovia Sul Goiana, km 01 - Zona Rural, Rio Verde, GO, osvresende@yahoo.com.br.

${ }^{3}$ Departamento de Proyectos e Ingenieria Rural, Escuela Técnica Superior de Ingenieros Agrónomos, Universidad Pública de Navarra, Campus Arrosadia, 31006 Pamplona, Spain, silvia.arazuri@unavarra.es;cjaren@unavarra.es.

${ }^{4}$ Professor M.Sc., Instituto Federal de Brasília,Câmpus Gama, Gama - DF, gabriel.oliveira@ifb.edu.br.

Recebido pelo Conselho Editorial em: 8-9-2009

Aprovado pelo Conselho Editorial em: 4-5-2011
} 
drying helps in the execution of projects and dimensioning of the equipment, as well as in understanding of the related processes.

Models that have been used to represent the drying of agricultural products were developed, to a large extent, without considering the volumetric shrinkage rate of the products during the dehydration process (BROOKER et al., 1992). These models are being revised to incorporate the parameter in order to improve the simulation of the dehydration process and guarantee the accuracy of the results (LANG \& SOKHANSANJ, 1993; BENNAMOUN \& BELHAMRI, 2006; HASHEMI et al., 2009).

Volumetric changes of the products due to dehydration are the primary cause of the alterations in the main physical properties of products (RATTI, 1994). According to RAMOS et al. (2005) and CARMO \& LIMA (2004), these changes should also be included in the models for a complete description and analysis of the phenomenon.

The removal of water during drying of biological products leads to cellular structural modifications due to reduced tension inside the cells. This phenomenon causes alterations in the shape and dimension of products. Such changes, according to YAN et al. (2007), affect the physical properties of products (including volume shrinkage rate) and modify the final texture and transport properties of dry foods.

RATTI (1994) observed that the volumetric shrinkage rate of plant products during drying does not depend exclusively on its moisture content, but also on the environmental conditions during the process and the geometry and constitution of the products.

The theoretical bases for the knowledge about the process of volumetric shrinkage rate are related to complex laws of mechanics and deformation of materials (TOWNER, 1987). However, various academic projects are being developed using approximations and empirical models, in an attempt to better represent this complex phenomenon in products of biological nature (MAYOR \& SERENO, 2004).

KHRAISHEH et al. (2004) observed that the volumetric shrinkage rate of agricultural products varies during drying. At the beginning of the drying process, products seem to keep their structure intact and maintain their original shape, but they shrink with water removal, which contributes for the distortion of particles.

CORRÊA et al. (2004) modeled the volumetric shrinkage rate of coffee berries during the drying of the product. The authors observed that it was not possible to adjust one single model to the three varieties in the study. The models Modified Bala \& Woods, Linear and a third model proposed by the authors were recommended to represent the volumetric shrinkage rate of the varieties and species "Catuaí Vermelho", "Mundo Novo" and "Conilon", respectively.

In the modeling of the drying process of agricultural products, several researchers describe the parameters that vary with temperature through the Arrhenius representation (CORRÊA et al., 2007; MOHAPATRA \& RAO, 2005; BABALIS \& BELESSIOTIS, 2004; RAMOS et al., 2004), in accordance with the following equation:

$$
\mathrm{k}=\mathrm{k}_{\mathrm{o}} \cdot \exp \left(\frac{-\mathrm{E}_{\mathrm{a}}}{\mathrm{R} \cdot \mathrm{T}_{\mathrm{a}}}\right)
$$

where,

$\mathrm{k}$ - parameter of the product that varies with temperature;

$\mathrm{k}_{\mathrm{o}}$ - pre-exponential factor;

$\mathrm{E}_{\mathrm{a}}$ - activation energy, $\mathrm{kJ} \mathrm{kmol}^{-1}$;

$\mathrm{R}$ - universal gas constant, $8.314 \mathrm{~kJ} \mathrm{kmol}^{-1} \mathrm{~K}^{-1}$, and

$\mathrm{T}_{\mathrm{a}}$ - absolute temperature, $\mathrm{K}$. 
Considering the absence of data in the specialized literature, the present work aimed to determine the volumetric shrinkage rate of bean (Phaseolus vulgaris L.) seeds during drying under different air conditions, and adjust different mathematical models to the experimental values, selecting the model that best describes this phenomenon.

\section{MATERIALS AND METHODS}

Bean seeds of the red group, hand picked, with moisture content of approximately $0.92(\mathrm{~kg}$ water $/ \mathrm{kg}$ dry matter) were used in this experiment. The moisture content of the product was determined through the stove method, $105 \pm 1^{\circ} \mathrm{C}$, until constant mass.

The drying of the product was performed at different conditions of controlled drying air temperature $\left(25 ; 35 ; 45\right.$ and $55^{\circ} \mathrm{C}$ ) and relative humidity (between 20 and $75 \%$ ), totaling fourteen different air conditions. Drying of the bean seeds was interrupted when the product reached hygroscopic equilibrium with the air.

The different conditions of air temperature and relative humidity were supplied by the use of an atmosphere conditioning unit. The air flow was monitored with a hot wire anemometer and kept constant at $4 \mathrm{~m}^{3} \mathrm{~s}^{-1} \mathrm{~m}^{-2}$. Air temperature and relative humidity were monitored by a psychrometer installed close to the trays where the samples were placed.

The volumetric shrinkage rate $(\phi)$ of the beans during drying was determined by the rate between the seed volume for each moisture content $\left(\mathrm{V}_{\mathrm{g}}\right)$ and the initial volume $\left(\mathrm{V}_{\mathrm{go}}\right)$.

$$
\phi=\frac{\mathrm{V}_{\mathrm{g}}}{\mathrm{V}_{\mathrm{go}}}
$$

where,

$\phi$ - volumetric shrinkage rate;

$\mathrm{V}_{\mathrm{g}}$ - volume for each moisture content, $\mathrm{m}^{3}$, and

$\mathrm{V}_{\mathrm{go}}$ - initial volume, $\mathrm{m}^{3}$.

We obtained the grain volume by measuring each grain in all three orthogonal axes (length, width and depth), considering the spheroid grain shape (Figure 1), as proposed by MOHSENIN (1986).

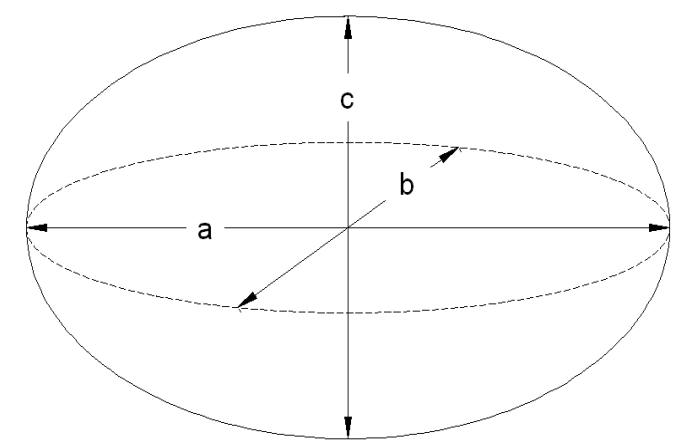

FIGURE 1. Schematic design of the bean grain, considered spherical-oblate, with its characteristic dimensions.

We determined the characteristic dimensions ( $a, b$ and $c$ ) with the aid of a digital caliper, $0.01 \mathrm{~mm}$ accuracy, in ten grains, during the drying process. The volume was described by the following equation:

$$
\mathrm{V}_{\mathrm{g}}=\frac{\pi \cdot \mathrm{a} \cdot \mathrm{b} \cdot \mathrm{c}}{6}
$$

where, 
a - longest grain axis, $\mathrm{mm}$;

$\mathrm{b}$ - average grain axis, $\mathrm{mm}$, and

$\mathrm{c}$ - shortest grain axis, $\mathrm{mm}$.

The experimental values of the volumetric shrinkage rate were adjusted to the mathematical models expressed by the following equations:

\begin{tabular}{lll}
\hline Model reference & Model \\
\hline MODIFIED BALA \& WOODS (1984) & $\phi=1-\mathrm{a} \cdot\left\{1-\exp \left[-\mathrm{b} \cdot\left(\mathrm{X}-\mathrm{X}_{\mathrm{o}}\right)\right]\right\}$ \\
LANG \& SOKHANSANJ (1993) & $\phi=\mathrm{a}+\beta_{1} \cdot\left(\mathrm{X}-\mathrm{X}_{\mathrm{O}}\right) ; \beta_{1}=\mathrm{a}+\mathrm{b} \cdot(\mathrm{RH})+\mathrm{c} \cdot(\mathrm{T})$ \\
RAHMAN (1995) & $\phi=1+\beta_{2} \cdot\left(\mathrm{X}-\mathrm{X}_{\mathrm{o}}\right)$ \\
CORRÊA et al. (2004) & $\phi=1 /(\mathrm{a}+\mathrm{b} \cdot \exp (\mathrm{X}))$ \\
Linear & $\phi=\mathrm{a}+\mathrm{b} \cdot \mathrm{X}$ \\
Exponential & $\phi=\mathrm{a} \cdot \exp (\mathrm{b} \cdot \mathrm{X})$
\end{tabular}

where,

$\mathrm{X}$ - moisture content of the product, $\mathrm{kg}$ water/kg dry matter;

$\mathrm{X}_{0}$ - initial moisture content of the product, $\mathrm{kg}$ water $/ \mathrm{kg}$ dry matter;

$\mathrm{RH}$ - relative humidity, decimal;

$\mathrm{T}$ - air temperature, ${ }^{\circ} \mathrm{C}$;

$\mathrm{a}, \mathrm{b}$ and $\mathrm{c}$ : fitted parameters of the models, dimensionless;

$\beta_{1}$ - volumetric shrinkage coefficient, dimensionless, and

$\beta_{2}$ - volumetric shrinkage coefficient, dimensionless.

We adjusted the mathematical models with a non-linear regression analysis, using the Gauss Newton method, with the aid of the STATISTICA 5.0® software system. The degree of fit for each model considered the significance of the regression coefficient in the $t$-test at $1 \%$ probability level, the value of the determination coefficient $\left(\mathrm{R}^{2}\right)$, the values of the mean relative error $(\mathrm{P})$ and mean estimated error (SE), and the prediction of the behavior of the distribution of residuals. The estimated and relative median errors, for each of the models, were calculated by the following equations:

$$
\begin{aligned}
& \mathrm{P}=\frac{100}{\mathrm{n}} \sum \frac{|\mathrm{Y}-\hat{\mathrm{Y}}|}{\mathrm{Y}} \\
& \mathrm{SE}=\sqrt{\frac{\sum(\mathrm{Y}-\hat{\mathrm{Y}})^{2}}{\mathrm{GLR}}}
\end{aligned}
$$

where,

$\mathrm{P}$ - mean relative error, \%;

SE - mean estimated error, \%;

Y - value observed empirically;

$\hat{Y}$ - value calculated by the model;

$\mathrm{n}$ - number of experimental observation, and

GLR - degrees of freedom of the model. 


\section{RESULTS AND DISCUSSION}

Figure 2 presents the experimental values of the volumetric shrinkage rate of bean seeds during drying under different conditions of air temperature and relative humidity.

A

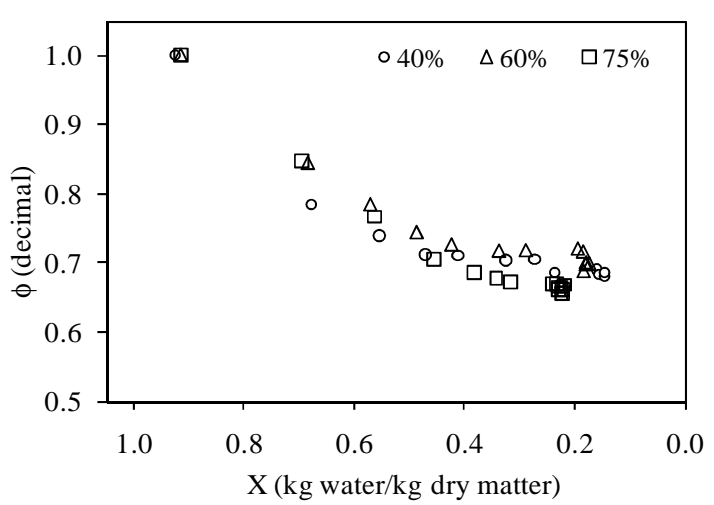

$\mathrm{C}$

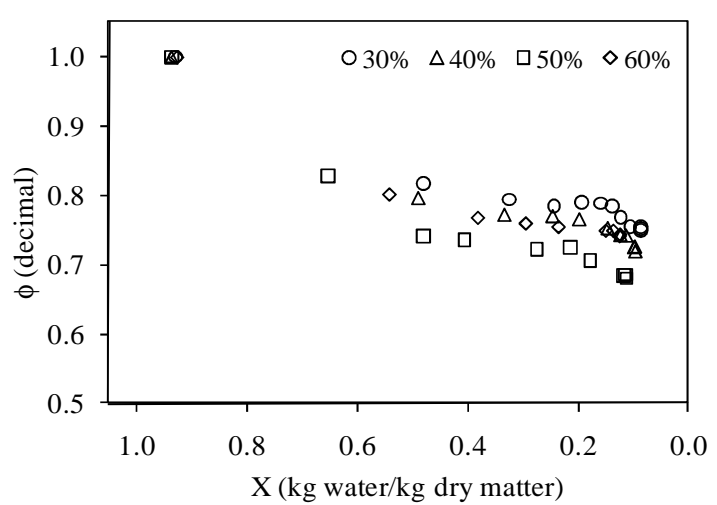

B

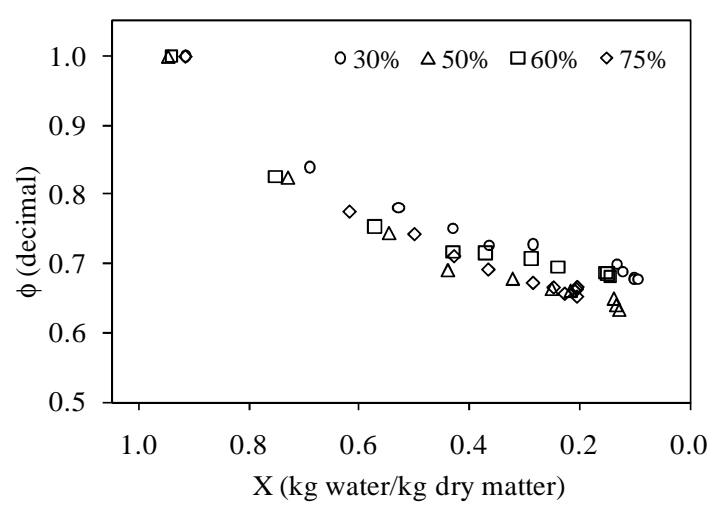

$\mathrm{D}$

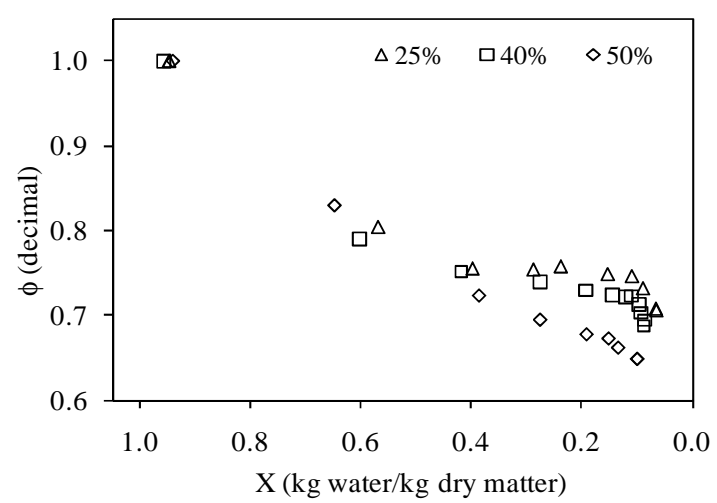

FIGURE 2. Experimental values of the volumetric shrinkage rate ( $\phi$, decimal), according to the conditions of moisture content $\left(\mathrm{X}, \mathrm{kg}\right.$ water/ $\mathrm{kg}$ dry matter) for $25^{\circ} \mathrm{C}(\mathrm{A}), 35^{\circ} \mathrm{C}(\mathrm{B}), 45$ ${ }^{\circ} \mathrm{C}(\mathrm{C})$ and $55^{\circ} \mathrm{C}(\mathrm{D})$, air temperature and relative humidity $(\%)$ during bean drying.

Figure 2 shows that the final volumetric shrinkage of bean seeds ranged between 0.75 and 0.63 for the different drying conditions, due to reduced initial grain volume of $25 \%$ to $37 \%$, directly related to the specific equilibrium moisture content for each air temperature and relative humidity condition. AFONSO JÚNIOR et al. (2004) observed a 39\% decrease in the volume of cherry coffee beans with an initial moisture content of 2.27 that was reduced to 0.11 ( $\mathrm{kg}$ water $/ \mathrm{kg}$ dry matter). RAMOS et al. (2005) observed a reduction of $35 \%$ of grape berries during drying, and pointed out that this significant variation in the volumetric shrinkage rate of the product must be included in mass transfer models. It is also evident that the shrinking rate of bean seeds is higher at the beginning of the drying, when moisture content is higher. At a lower moisture content, the volumetric shrinkage rate does not reflect accurately the loss of water during drying. We found that the effect of the drying air temperature and relative humidity can be neglected in the volumetric shrinkage rate process. Similar results were obtained by TALHA et al. (2004) in a study on the volumetric shrinkage rate of banana during drying, under different air conditions.

Tables 1 and 2 present the values of coefficients of determination, relative and estimated mean errors, and the trend of the distribution of the residuals for the six models analyzed, during the drying of bean seeds under different conditions of air temperature and relative humidity. 
Table 1 shows that, for all fourteen combinations of air temperature and relative humidity conditions used during the drying of bean seeds, the Modified Bala \& Woods' model offered higher values for coefficient of determination $\left(\mathrm{R}^{2}\right)$ and lower values for relative and estimated mean error, compared to the other models analyzed. Table 2 also demonstrates that this model presents a random distribution of the residuals for all drying conditions. Therefore, the Modified Bala \& Woods' model proved to be adequate for the mathematical description of the volumetric shrinkage rate of bean seeds.

TABLE 1. Determination coefficients $\left(\mathrm{R}^{2}, \%\right)$, mean relative error $(\mathrm{P}, \%)$, mean estimated error (SE, decimal), for the six models adjusted to the data of volumetric shrinkage rate during the drying of bean at air temperatures of $25^{\circ} \mathrm{C}, 35^{\circ} \mathrm{C}, 45^{\circ} \mathrm{C}$ and $55^{\circ} \mathrm{C}$.

\begin{tabular}{|c|c|c|c|c|c|c|c|c|c|c|c|c|}
\hline & \multicolumn{12}{|c|}{ Temperature $25^{\circ} \mathrm{C}$} \\
\hline RH & \multicolumn{4}{|c|}{$40 \%$} & \multicolumn{4}{|c|}{$60 \%$} & \multicolumn{4}{|c|}{$75 \%$} \\
\hline Model & $\mathrm{R}$ & & SE & $\mathrm{P}$ & $\mathrm{R}^{2}$ & & $\mathrm{SE}$ & $\mathrm{P}$ & $\mathrm{R}^{2}$ & & SE & $\mathrm{P}$ \\
\hline$(4)$ & 99 & & .010 & 0.85 & 98. & & 0.011 & 1.07 & 99.2 & & 0.010 & 0.90 \\
\hline$(5)$ & 74 & & .049 & 4.46 & 84. & & 0.038 & 3.47 & 93.4 & & 0.031 & 2.66 \\
\hline (6) & 54 & & .065 & 6.21 & 73. & & 0.050 & 4.78 & 90.0 & & 0.038 & 3.40 \\
\hline (7) & 91 & & .029 & 2.82 & 96. & & 0.019 & 1.82 & 99.1 & & 0.011 & 0.99 \\
\hline (8) & 84 & & .038 & 3.47 & 84. & & 0.038 & 3.47 & 93.4 & & 0.031 & 2.66 \\
\hline \multirow[t]{2}{*}{$(9)$} & 87 & & .034 & 3.21 & 87. & & 0.034 & 3.21 & 95.8 & & 0.024 & 2.21 \\
\hline & \multicolumn{12}{|c|}{ Temperature $35^{\circ} \mathrm{C}$} \\
\hline RH & \multicolumn{3}{|c|}{$30 \%$} & \multicolumn{3}{|c|}{$50 \%$} & \multicolumn{3}{|c|}{$60 \%$} & \multicolumn{3}{|c|}{$75 \%$} \\
\hline Model & $\mathrm{R}^{2}$ & SE & $\mathrm{P}$ & $\mathrm{R}^{2}$ & SE & $\mathrm{P}$ & $\mathrm{R}^{2}$ & $\mathrm{SE}$ & $\mathrm{P}$ & $\mathrm{R}^{2}$ & $\mathrm{SE}$ & $\mathrm{P}$ \\
\hline$(4)$ & 99.5 & 0.007 & 0.77 & 99.7 & 0.007 & 0.75 & 99.7 & 0.005 & 0.51 & 97.9 & 0.015 & 1.27 \\
\hline (5) & 91.2 & 0.030 & 2.88 & 91.4 & 0.034 & 3.23 & 85.6 & 0.038 & 3.38 & 86.7 & 0.039 & 3.65 \\
\hline (6) & 84.1 & 0.041 & 4.13 & 85.6 & 0.044 & 4.26 & 73.8 & 0.051 & 4.68 & 81.3 & 0.046 & 4.47 \\
\hline (7) & 99.2 & 0.009 & 0.99 & 99.4 & 0.009 & 0.78 & 96.7 & 0.018 & 1.72 & 96.7 & 0.019 & 1.69 \\
\hline (8) & 91.2 & 0.030 & 2.88 & 91.4 & 0.034 & 3.23 & 85.6 & 0.038 & 3.38 & 86.7 & 0.039 & 3.65 \\
\hline (9) & 93.9 & 0.025 & 2.48 & 94.5 & 0.027 & 2.68 & 88.7 & 0.033 & 3.10 & 90.3 & 0.033 & 3.17 \\
\hline & \multicolumn{12}{|c|}{ Temperature $45^{\circ} \mathrm{C}$} \\
\hline RH & \multicolumn{3}{|c|}{$30 \%$} & \multicolumn{3}{|c|}{$40 \%$} & \multicolumn{3}{|c|}{$50 \%$} & \multicolumn{3}{|c|}{$60 \%$} \\
\hline Model & $\mathrm{R}^{2}$ & $\mathrm{SE}$ & $\mathrm{P}$ & $\mathrm{R}^{2}$ & SE & $\mathrm{P}$ & $\mathrm{R}^{2}$ & SE & $\mathrm{P}$ & $\mathrm{R}^{2}$ & $\mathrm{SE}$ & $\mathrm{P}$ \\
\hline$(4)$ & 96.7 & 0.014 & 1.27 & 98.0 & 0.012 & 1.18 & 98.7 & 0.011 & 1.24 & 99.8 & 0.003 & 0.31 \\
\hline$(5)$ & 93.0 & 0.020 & 1.61 & 93.8 & 0.020 & 1.67 & 90.0 & 0.031 & 2.78 & 88.5 & 0.026 & 2.85 \\
\hline (6) & 91.9 & 0.022 & 1.55 & 92.6 & 0.022 & 1.70 & 85.0 & 0.038 & 3.48 & 85.4 & 0.030 & 3.13 \\
\hline (7) & 96.8 & 0.014 & 1.28 & 98.1 & 0.011 & 1.23 & 98.2 & 0.013 & 1.14 & 97.7 & 0.012 & 1.27 \\
\hline (8) & 93.0 & 0.020 & 1.61 & 93.8 & 0.020 & 1.67 & 90.0 & 0.031 & 2.78 & 88.5 & 0.026 & 2.85 \\
\hline \multirow[t]{2}{*}{$(9)$} & 94.3 & 0.018 & 1.53 & 95.3 & 0.018 & 1.55 & 92.7 & 0.026 & 2.43 & 91.1 & 0.023 & 2.53 \\
\hline & \multicolumn{12}{|c|}{ Temperature $55^{\circ} \mathrm{C}$} \\
\hline RH & \multicolumn{4}{|c|}{$25 \%$} & \multicolumn{4}{|c|}{$40 \%$} & \multicolumn{4}{|c|}{$50 \%$} \\
\hline Model & & $\mathrm{R}^{2}$ & $\mathrm{SE}$ & $\mathrm{P}$ & $\mathrm{R}$ & & SE & $\mathrm{P}$ & $\mathrm{R}^{2}$ & & $\mathrm{SE}$ & $\mathrm{P}$ \\
\hline$(4)$ & & 94.5 & 0.021 & 2.12 & 98 & & 0.010 & 0.99 & 99.8 & & 0.004 & 0.45 \\
\hline (5) & & 92.3 & 0.025 & 2.16 & 88 & & 0.031 & 2.43 & 97.2 & & 0.018 & 2.04 \\
\hline (6) & & 91.7 & 0.026 & 2.02 & 83 & & 0.037 & 2.81 & 96.1 & & 0.022 & 2.33 \\
\hline (7) & & 93.8 & 0.023 & 2.04 & 97 & & 0.015 & 1.37 & 99.5 & & 0.008 & 0.83 \\
\hline (8) & & 92.3 & 0.025 & 2.16 & 88 & & 0.031 & 2.43 & 97.2 & & 0.018 & 2.04 \\
\hline (9) & & 93.5 & 0.023 & 2.03 & 91 & & 0.027 & 2.23 & 98.7 & & 0.012 & 1.43 \\
\hline
\end{tabular}


TABLE 2. Behavior of the distribution of residuals, showing trend (Td), or at random (A), for the six models analyzed, during the drying of beans under different conditions of air temperature and relative humidity (RH \%).

\begin{tabular}{|c|c|c|c|c|c|c|c|c|c|c|c|c|c|c|}
\hline & \multicolumn{14}{|c|}{ Temperature $\left({ }^{\circ} \mathrm{C}\right)$} \\
\hline & \multicolumn{3}{|c|}{$25^{\circ} \mathrm{C}$} & \multicolumn{4}{|c|}{$35^{\circ} \mathrm{C}$} & \multicolumn{4}{|c|}{$45^{\circ} \mathrm{C}$} & \multicolumn{3}{|c|}{$55^{\circ} \mathrm{C}$} \\
\hline & \multicolumn{3}{|c|}{ RH (\%) } & \multicolumn{3}{|c|}{ RH (\%) } & & \multicolumn{4}{|c|}{ RH (\%) } & \multicolumn{3}{|c|}{ RH (\%) } \\
\hline Model & 40 & 60 & 75 & 30 & 50 & 60 & 75 & 30 & 40 & 50 & 60 & 25 & 30 & 40 \\
\hline (4) & A & A & A & A & A & A & A & A & A & A & A & A & A & A \\
\hline (5) & $\mathrm{Td}$ & $\mathrm{Td}$ & $\mathrm{Td}$ & $\mathrm{Td}$ & $\mathrm{Td}$ & $\mathrm{Td}$ & $\mathrm{Td}$ & $\mathrm{Td}$ & $\mathrm{Td}$ & $\mathrm{Td}$ & $\mathrm{Td}$ & $\mathrm{Td}$ & $\mathrm{Td}$ & $\mathrm{Td}$ \\
\hline (6) & $\mathrm{Td}$ & $\mathrm{Td}$ & $\mathrm{Td}$ & $\mathrm{Td}$ & $\mathrm{Td}$ & $\mathrm{Td}$ & $\mathrm{Td}$ & $\mathrm{Td}$ & $\mathrm{Td}$ & $\mathrm{Td}$ & $\mathrm{Td}$ & $\mathrm{Td}$ & A & $\mathrm{Td}$ \\
\hline (7) & $\mathrm{Td}$ & A & A & A & $\mathrm{Td}$ & $\mathrm{Td}$ & $\mathrm{Td}$ & A & A & A & $\mathrm{Td}$ & A & $\mathrm{Td}$ & $\mathrm{Td}$ \\
\hline (8) & $\mathrm{Td}$ & $\mathrm{Td}$ & $\mathrm{Td}$ & $\mathrm{Td}$ & $\mathrm{Td}$ & $\mathrm{Td}$ & $\mathrm{Td}$ & $\mathrm{Td}$ & $\mathrm{Td}$ & $\mathrm{Td}$ & $\mathrm{Td}$ & $\mathrm{Td}$ & $\mathrm{Td}$ & $\mathrm{Td}$ \\
\hline (9) & $\mathrm{Td}$ & $\mathrm{Td}$ & $\mathrm{Td}$ & $\mathrm{Td}$ & $\mathrm{Td}$ & $\mathrm{Td}$ & $\mathrm{Td}$ & $\mathrm{Td}$ & $\mathrm{Td}$ & $\mathrm{Td}$ & $\mathrm{Td}$ & $\mathrm{Td}$ & $\mathrm{Td}$ & $\mathrm{Td}$ \\
\hline
\end{tabular}

Figure 3 presents the comparison of the models adjusted to the experimental values of volumetric shrinkage rate for air temperature of $25^{\circ} \mathrm{C}$, and $40 \%$ of relative humidity during the drying of the bean, demonstrating that the Modified Bala \& Woods' model was the best of all models analyzed.

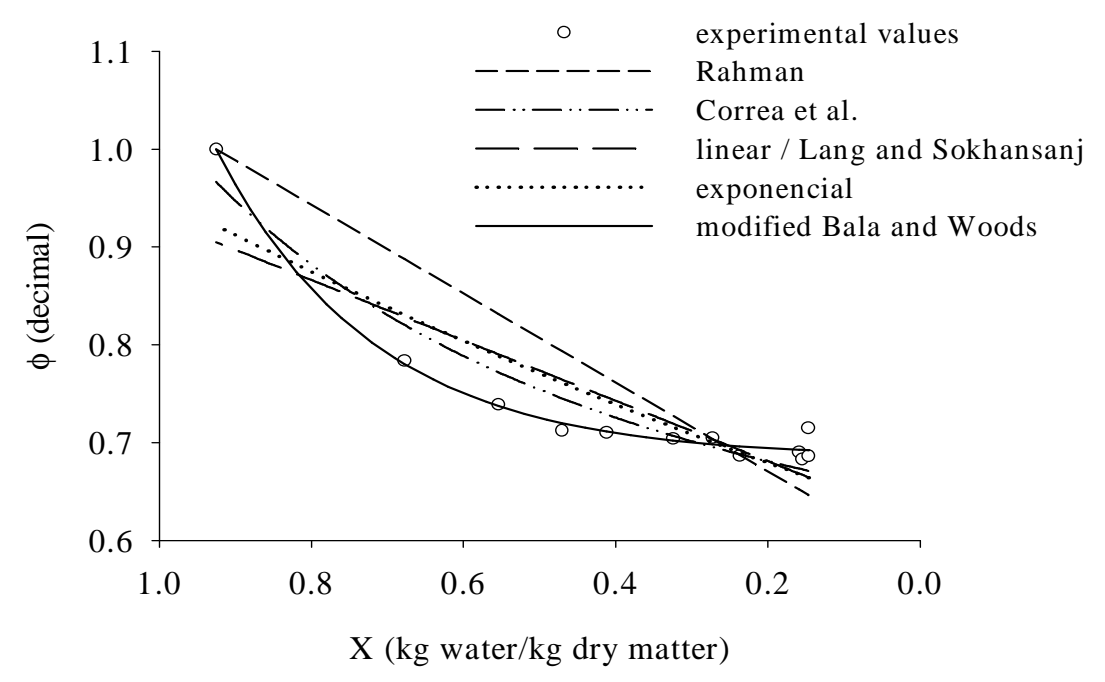

FIGURE 3. Comparison of the models adjusted to the experimental values of volumetric shrinkage rate for air temperature of $25^{\circ} \mathrm{C}$ and $40 \%$ of relative humidity during bean drying.

CORRÊA et al. (2004) also observed that the Modified Bala \& Woods' model was the one that best fitted the experimental values of the volumetric shrinkage rate of coffee berries during the drying process.

The estimated coefficients used in the description of the volumetric shrinkage rate of beans for different conditions of air temperature and relative humidity for the Modified Bala \& Woods' model are presented in Table 3.

In general, we observe in Table 3 that the coefficient "a" for the Modified Bala \& Woods" model does not clearly correlate with air temperature and relative humidity. The coefficient " $b$ " presents a similar behavior in relation to relative humidity, when temperature is maintained constant. 
TABLE 3. Coefficients of the Modified Bala \& Woods' model, adjusted to represent the volumetric shrinkage rate of bean grains at different conditions of temperature $(\mathrm{T})$ and relative humidity (RH) of the drying air.

\begin{tabular}{cccccccc}
\hline \multicolumn{2}{c}{ Air Condition } & \multicolumn{2}{c}{ Coefficients } & \multicolumn{2}{c}{ Air Condition } & \multicolumn{2}{c}{ Coefficients } \\
\hline $\mathrm{T}\left({ }^{\circ} \mathrm{C}\right)$ & $\mathrm{RH}(\%)$ & $\mathrm{A}$ & $\mathrm{b}$ & $\mathrm{T}\left({ }^{\circ} \mathrm{C}\right)$ & $\mathrm{RH}(\%)$ & $\mathrm{a}$ & $\mathrm{b}$ \\
\hline \multirow{2}{*}{25} & 40 & $0.3153^{* *}$ & $4.8139^{* *}$ & & 25 & $0.4534^{* * *}$ & $1.0880^{* *}$ \\
& 60 & $0.3208^{* *}$ & $3.3399^{* *}$ & 55 & 40 & $0.3116^{* *}$ & $2.9917^{* *}$ \\
& 75 & $0.4291^{* *}$ & $2.2940^{* *}$ & & 50 & $0.4877^{* *}$ & $1.4822^{* *}$ \\
\hline \multirow{3}{*}{35} & 30 & $0.3631^{* * *}$ & $2.4462^{* *}$ & & 30 & $0.2999^{* * *}$ & $1.8791^{* *}$ \\
& 50 & $0.4083^{* *}$ & $2.5664^{* *}$ & 45 & 40 & $0.3247^{* *}$ & $1.9853^{* *}$ \\
& 60 & $0.3278^{* *}$ & $3.8510^{* *}$ & 4 & 50 & $0.3518^{* *}$ & $2.5503^{* *}$ \\
& 75 & $0.3729^{* *}$ & $3.2275^{* *}$ & & 60 & $0.2744^{* *}$ & $3.2740^{* *}$ \\
\hline
\end{tabular}

${ }^{* * *}$ Significant at $1 \%$ probability level by the $t$-test.

However, when the air temperature raises (Table 3) the coefficient " $b$ " decreases. Its influence on the volumetric shrinkage rate of the bean during the drying process could be described through the Arrhenius representation, as indicated in Figure 4.

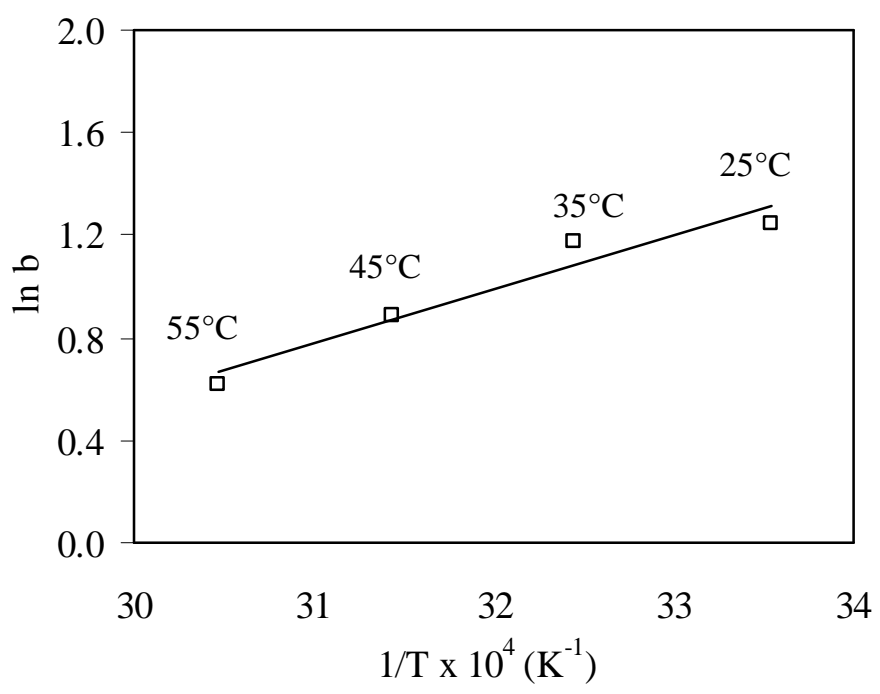

FIGURE 4. Arrhenius representation of the coefficient " $b$ " in the Modified Bala \& Woods' model during the drying of the bean.

Based on the Arrhenius representation, we can conclude that the coefficient " $b$ " of the Modified Bala \& Woods' model presented a linear variation throughout the drying of the bean, demonstrating that the variation rate of the phenomenon remained uniform within the temperature range used in the study.

Equation 12 shows the values of the constants adjusted for the coefficient " $b$ " of the Modified Bala \& Woods' model, as calculated from equation 1, and used for the description of the bean volumetric shrinkage rate.

$$
\mathrm{b}=0.00552 \cdot \exp \left(\frac{15736.5}{\mathrm{R} \cdot \mathrm{T}_{\mathrm{a}}}\right)
$$

The activation energy for bean shrinkage was $15.7 \mathrm{~kJ} \mathrm{~mol}^{-1}$ for temperatures between $25{ }^{\circ} \mathrm{C}$ and $55^{\circ} \mathrm{C}$, a value slightly lower than those reported in literature for the drying of green bean, $35.4 \mathrm{~kJ} \mathrm{~mol}^{-1}$ (DOYMAZ, 2005); carrot, $28.36 \mathrm{~kJ} \mathrm{~mol}^{-1}$ (DOYMAZ, 2004); Macassar bean, 
$26.9 \mathrm{~kJ} \mathrm{~mol}^{-1}$ (SILVA et al., 2008). However, ZOGZAS et al. (1996) pointed out that the activation energy of agricultural products ranges between 12.7 and $110.0 \mathrm{~kJ} \mathrm{~mol}^{-1}$.

Thus, by the use of the average value of the coefficient "a" of the Modified Bala \& Woods' model expected for the different air conditions, the volumetric shrinkage rate of bean during the drying of the product within the temperature range studied is expected to be described by the equation:

$$
\phi=1-0.3562 \cdot\left(1-\exp \left(-1 \cdot 0.005523 \cdot \exp \left(\frac{15736.51}{8.314 \cdot(\mathrm{T}+273)}\right) \cdot\left(\mathrm{X}-\mathrm{X}_{\mathrm{o}}\right)\right)\right)
$$

This equation presents a maximum mean relative error of $2.12 \%$ and lowest determination coefficient of $94.5 \%$ (Table 1) at storage conditions of $55^{\circ} \mathrm{C}$ and $25 \%$.

Figure 5 displays the values of the volumetric shrinkage rate, both experimental and calculated with the Modified Bala \& Woods' model, during the drying process of red bean under different conditions of air temperature and relative humidity.

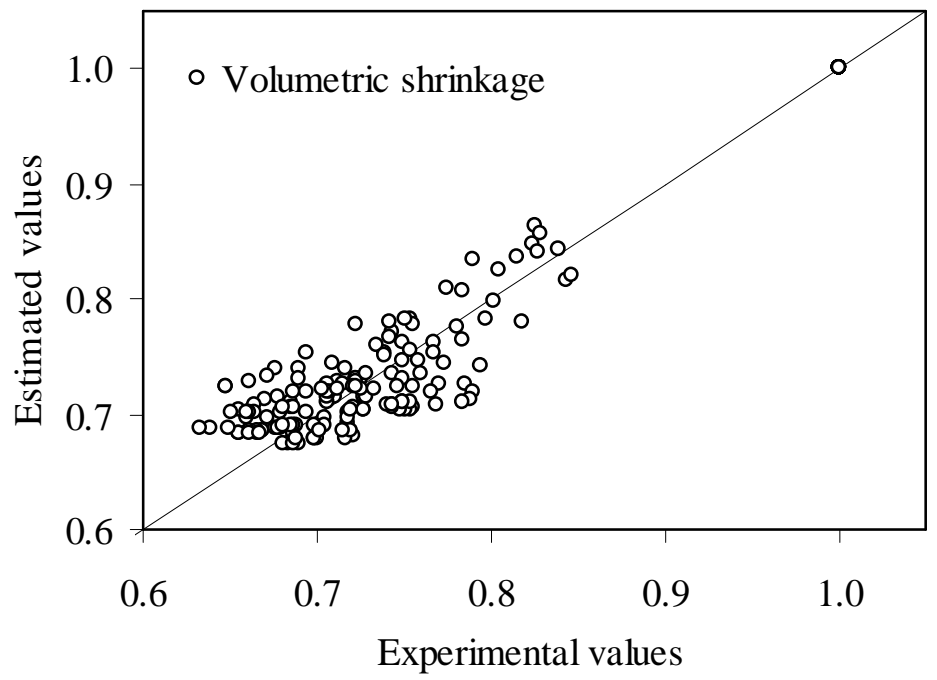

FIGURE 5. Values of the volumetric shrinkage rate, experimental and expected by the Modified Bala \& Woods' model, during drying of bean under different temperature and relative humidity conditions.

\section{CONCLUSIONS}

Based on the results obtained, we conclude that the volumetric reduction of red bean seeds ranges between 25 and $37 \%$ during drying, basically depending on the final moisture content, and almost independently from the air conditions during drying. Among the models tested, the Modified Bala \& Woods' model best represents the phenomenon of volumetric shrinkage rate of beans during the drying process.

\section{ACKNOWLEDGMENTS}

The authors would like to acknowledge the agencies of the Brazilian government CAPES, CNPq and FAPEMIG, for their financial support, which was essential for the completion of this research.

\section{REFERENCES}

AFONSO JÚNIOR, P.C.; CORRÊA, P.C.; GONELI, A.L.D.; VILARINHO, M.C.; FRANÇA, A.S. Dinâmica da contração volumétrica do fruto de café durante o processo de secagem. Revista Brasileira de Armazenamento, Viçosa-MG, n.8, p.29-35, 2004. Número Especial. 
BABALIS, S.J.; BELESSIOTIS, V.G. Influence of the drying conditions on the drying constants and moisture diffusivity during the thin-layer drying of figs. Journal of Food Engineering, v.65, p.449-458, 2004.

BALA, B.K.; WOODS, J.L. Simulation of deep bed malt drying. Journal of Agricultural Engineering Research, London, v.30, n.3, p.235-244, 1984.

BENNAMOUN, L.; BELHAMRI, A. Numerical simulation of drying under variable external conditions: application to solar drying of seedless grapes. Journal of Food Engineering, Essex, v.76, n.2, p.179-187, 2006.

BROOKER, D.B.; BAKKER-ARKEMA, F.W.; HALL, C.W. Drying and storage of grains and oilseeds. Westport: The AVI Publishing Company, 1992. 450 p.

CARMO, J.E.F.; LIMA, A.G.B. Drying of lentils including shrinkage: a numerical simulation. In: INTERNATIONAL DRYING SYMPOSIUM, 14., 2004, São Paulo. Proceedings... CD ROM.

CORRÊA, P.C.; RESENDE, O.; MARTINAZZO, A.P.; GONELI, A.L.D.; BOTELHO, F.M. Modelagem matemática para a descrição do processo de secagem do feijão (Phaseolus vulgaris L.) em camadas delgadas. Engenharia Agrícola, Jaboticabal, v.27, n.2, p.501-510, 2007.

CORRÊA, P.C.; RIBEIRO, D.M.; RESENDE, O.; AFONSO JÚNIOR, P.C.; GONELI, A.L.D. Mathematical modeling for representation of coffee berry volumetric shrinkage. In: INTERNATIONAL DRYING SYMPOSIUM, 14., 2004, São Paulo. Proceedings... CD ROM.

DOYMAZ, I. Convective air drying characteristics of thin layer carrots. Journal of Food Engineering, Essex, v.61, p.359-364, 2004.

DOYMAZ, I. Drying behavior of green beans. Journal of Food Engineering, Essex, v.69, p.161$165,2005$.

HASHEMI, G.; MOWLAB, D.; KAZEMEINI, M. Moisture diffusivity and shrinkage next term of broad beans during bulk drying in an inert medium fluidized bed dryer assisted by dielectric heating. Journal of Food Engineering, Essex, v.92, n.3, p.331-338, 2009.

KHRAISHEH, M.A.M.; MCMINN, W.A.M.; MAGEE, T.R.A. Quality and structural changes in starchy foods during microwave and convective drying. Food Research International, Barking, v.34, p.497-503, 2004.

LANG, W.; SOKHANSANJ, S. Bulk volume shrinkage during drying of wheat and canola. Journal of Food Process Engineering, Westport, v.16, n.4, p.305-314, 1993.

MAYOR, L.; SERENO, A.M. Modeling shrinkage during convective drying of food materials: a review. Journal of Food Engineering, Essex, v.61, p.373-386, 2004.

MOHAPATRA, D.; RAO, P.S. A thin layer drying model of parboiled wheat. Journal of Food Engineering, Essex, v.66, n.4, p.513-518, 2005.

MOHSENIN, N.N. Physical Properties of Plant and Animal Materials. New York: Gordon and Breach Publishers, 1986. 841 p.

RAHMAN, S. Food properties handbook. Boca Raton: CRC Press LLC, 1995. 500 p.

RAMOS, I.N.; BRANDÃO, T.R.S.; SILVA, C.L.M. Integrated approach on solar drying, pilot convective drying and microstructural changes. Journal of Food Engineering, Essex, v.67, p.195203, 2005.

RAMOS, I.N.; SILVA, C.L.M.; SERENO A.M.; AGUILERA, J.M. Quantification of microstructural changes during first stage air drying of grape tissue. Journal of Food Engineering, Essex, v.62, p.159-164, 2004. 
RATTI, C. Shrinkage during drying of foodstuffs. Journal of Food Engineering, Essex, v.23, n.1, p.91-105, 1994.

SILVA, W.P.; CAVALCANTI-MATA, M.E.R.M.; SILVA, C.D.P.S.; GUEDES, M.A.; LIMA, A.G.B. Determinação da difusividade e da energia de ativação para feijão Macassar (Vigna unguiculata (L.) Walp.), variedade sempre-verde, com base no comportamento da secagem. Engenharia Agrícola, Jaboticabal, v.28, n.2, p.325-333, 2008.

TALHA, A.; PUIGGAL, J.R.; JOMAA, W.; JANNOT, Y. Shrinkage and density evolution during drying of tropical fruits: application to banana. Journal of Food Engineering, Essex, v.64, p.103109, 2004.

TOWNER, G.D. The tensile stress generated in clay through drying. Journal Agricultural Engineering Research, London, v.37, n.4, p.279-289, 1987.

YAN, Z.; SOUSA-GALLAGHER, J.M.; OLIVEIRA, A.R.F. Shrinkage and porosity of banana, pineapple and mango slices during air-drying. Journal of Food Engineering, Essex, v.83, n.3, p.430-440, 2007.

ZOGZAS, N.P.; MAROULIS, Z.B.; MARINOS-KOURIS, D. Moisture diffusivity data compilation in foodstuffs. Drying Technology, New York, v.14, n.10, p.2.225-2.253, 1996. 